\title{
水・底質モデルによる瀬戸内海の 水質管理に関する研究
}

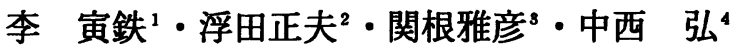 \\ ${ }^{1}$ 学生員工修 山口大学大学院博士後期課程（ 7755 宇部市常盤台2557） \\ ${ }^{2}$ 正会員 工博 山口大学教授 工学部社会建設工学科（元755 宇部市常整台2557） \\ ${ }^{3}$ 正会員 工博 山口大学助教授 工学部社会建設工学科 (下755 宇部市常盤台2557) \\ ${ }^{4}$ 正会員 工博 大阪工業大学教授 土木工学科（テ535 大阪市旭区大宮5-16-1）
}

\begin{abstract}
瀬戸内海を対象として, 水・底質の間の溶存酸素と栄举塩の授受による水質の季節変化モテルを作成し，

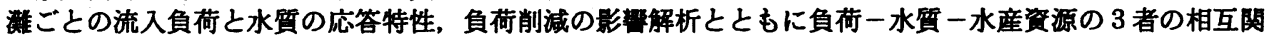
連性から水筫管理について検討した. 1957年から1987年までの負荷による水質の経年変化を調へ，淮ごと

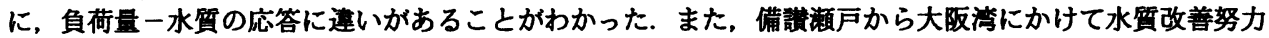
が必要なことがわかった. 負荷削減後の水質予測に対する概算式を提案した. 負荷削減効果の影算解析よ り、リンのみならす窒素の負荷削減の影第が大きいことを示した．負荷と水産資源の関逶性を検討より， 負荷の增加は一次生産の增加につながるが, 2 次生産以降のエネルギーの伝達には限度があることを示した。
\end{abstract}

Key Words : water-sediment quality model, loading abatement, pollutant load, primary production water quality management

\section{1. まえがき}

海域利用の要請が高い沿岸海域と閉鎖性の内湾で は, 半島や島による遮蔽効果で海水の流れは弱く， また，陸地から大量の污染物質が流入し，水・底質 の污染が進んでいる.このため, 赤潮, 富栄養化な ど海域利用上さまざまな不都合が生じ，海の機能を 著しく低下させている，したがって，海域の環境保 全を図りつつ，必要に応じ新たな環境を㓣造してい く必要がある.このためには，海域環境の現状を十 分考虑した上での環境測定や多分野にわたる分析の 蓄積などによる水質, 底質, 生物相などを把握する ことが最重要である。

海域の水質や生㮩系に関する数值モデルはこうし て得られた知識, 情報をもとに構築され, 条件変化 による環境影響評価や環境改善効果予測等の一手段 として頻繁に利用されている. しかしながらここの 種の数值モデルはいまだ確立されたものはなく，予 測目的に応じてさまざまな形態をとっているのが現 状である.

従来の海域の水質予測モテルは，環境基準である C O Dを中心とした, 夏季のみの平面分布を求める ことに主眼がおかれていた. しかしながら，環境基
準値のC O DやDＯといった水質目標により海の環 境を評価するのには限界があり, 海洋の生㮩系の内 部機構がどのように変化するかについては必ずしも 適切な情報が得られない，最近では，COD負荷の みを削減してもこうした閒鎖性海域の水質が改善さ れないことから，CODに加えて窒素, リン等につ いての環境基準が設定され，その類型指定の作業が 進められている ${ }^{1)}$ 。この栄巻塩物質の中で特に影響 が大きいのが窒素とリンであり，その挙動を把握す ることが富栄養化対策の 1 つとして取り上げられる. 内田ら ${ }^{2)}$ は富栄䖭化の進んだ海域において，COD を非保存物質として, 陸地から流入する 1 次 C O D と 2 次 C OD (内部生産) に分けて取り扱った. こ のモテルでは対象海域の栄養塩の内部生産の制限因 子がリンであることから, 栄養塩としてはリンのみ を取り上げている. また, 中田ら ${ }^{3)}$ は海域上層の生 産層と下層の非生産層とに分け, リンを循環物質と した動物, 植物プランクトン間の循環を取り扱って, 植物プランクトンの一次生産を窒素およびリンのう ち制限の強い方を用いて評価した. そして，岸ら“ と松梨 ${ }^{5)}$ は水質の季節的な変化を予测するモテルと して窒素・リンの循環に溶存酸素を加えたモデルを 提案している.この結果によれば，水質は空間的に 


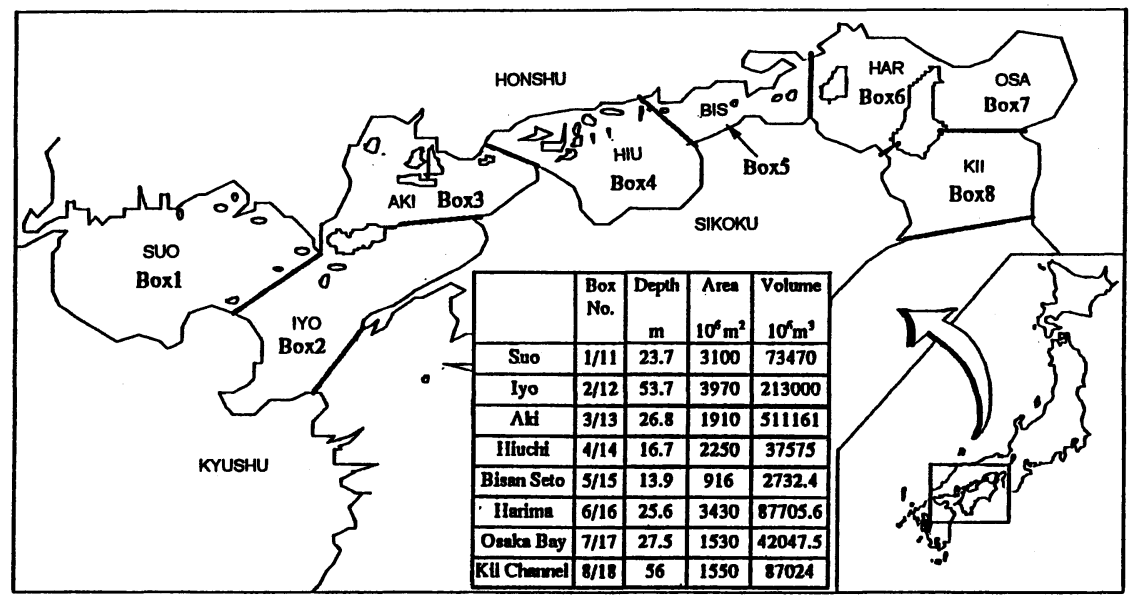

Fig. 1 Division of the eight boxes two layers model in Seto-Inland Sea.

も季節的にも変化し，特に生物の生息にとって重要 な溶存酸素は，湾奥下層での季節変化が著しいこと を指摘している.しかしながら，これらの報告では， 底泥と水層との間の相互作用について十分には考虑 されていない.

海域の水質は底泥に堆積した有機物が分解され栄 養塩が再び溶出, ゆっくりと水中に作用することに より, 負荷量と水質濃度の変化には時間的なずれが 存在する. また，水質と底質の平衡にはかなりの時 間かかかるため, 負荷量削减の効果に時間遅れも生 じる.こういった点で近年底泥と水層の作用が注目 されているところである. したがって，栄㧔塩の挙 動を考える場合, 底質が水質に与える影響を無視す ることはできない，これに関連して，浮田ら ${ }^{6)}$ は富 栄盖化海域への水・底質予測のためのシミュレーシ ョンモデルの原型を提案し，さらに，その応用とし て大阪湾の水質経年変化を再現することを試みてい $3^{7)}$. 水之底泥の間の物質交換のモテル化において は，とくにリンの挙動をうまく表現することが重要 である. すなわち, 溶存酸素, 硫化物, 酸化鉄が関 与し, 酸化層の消長に伴うリンの吸脱着, 溶出の著 しい季節変化を表現することが必要である. しかし， このような水と底泥の間の物質交換, 特にリンの交 換における特徵ある季節変化を表現したモテルは少 ない.

一方, 環境変化に対する魚介類への影響, 海洋生 産力の推定などを扱うのであれば, 少なくとも対象 とする生物まではモテルに組み込まない限り目的を 達しない，その場合，各過程を支配する式やパラメ 一夕も当然増える. しかし，この種の利用できる情 報や精度の質は一般に低いのが現状である. 言い 換えれば，モテルの形式や取扱いは複雑になっても
モテル全体の精度の上では必ずしも向上ということ には直結しない. したがって, パラメータの多い複 雑なモテルが必ずしもよりすぐれているとは限らず, 富栄養化のメカニズムを反映した簡易で適切なモテ ルも大局を判断するには有効である．

本研究では, 既報のモデル から高次生物項の導 入および硝化・脱窒のメカニズムの導入などの改良 を加え, 瀬戸内海を対象とした多ボックスの水・底 質間の溶存酸素と栄養塩の授受を含めた水質の季節 変化モテルを作成した．また，このモテルを用いて， 灘ごとの負荷と水質の応答特性, 負荷削減の影㸷解 析とともに負荷一水質一水産資源の 3 者の相互関連 性から水質管理について研究を行った.

\section{2. 水・底貫モデルの内容}

\section{（1）モデルの模成}

モデルは流動予測モテルと水・底質予測モテルよ り成る. しかし，流動および水質について，ともに 差分メッシュのモデルよって季節的な変化を計算 することは，計算量が膨大となり，現段階では実用 的でないため, 本モテルでは，流動については差分 メッシュモテルを，水質についてはボックスモデル を用いた. また，水質計算時のボックス間の水交換 は，潮汐流は渦とみなし，恒流成分が計算の対象と なる，恒流成分には，潮汐残差流，密度流，吹送流 などが存在するが, 本モテルでは，月単位程度の季 節変化を再現することを目的としているので, 主体 をなす潮汐残差流と，河川の流入による流れのみを 取り上げる. その際，河川流量には季節変化を考息 した. 計算場は陸地からの河川流量と流入負荷量が 灌間でかなり異なることと，環境庁 ${ }^{8)}$ の水梁，地形 
Table 1 Basic equations of the WSQM.

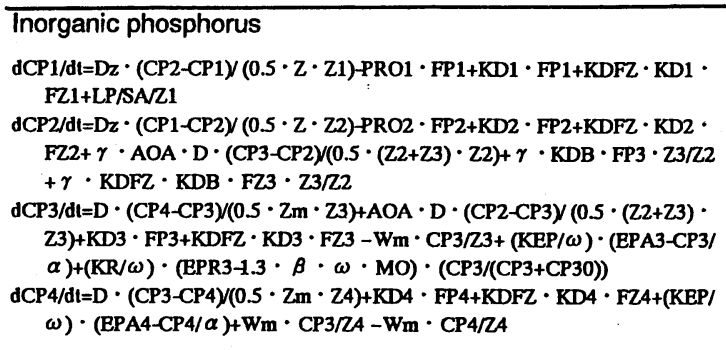

Phytoplankton phosphorus

$\mathrm{dFP} 1 / \mathrm{dt}=\mathrm{Rdz} \cdot \mathrm{Dz} \cdot(\mathrm{FP} 2$ FP1) $(0.5 \cdot \mathrm{Z} \cdot \mathrm{Z} 1)+\mathrm{PRO} \cdot \mathrm{FP} 1 \mathrm{KD} 1 \cdot \mathrm{FP} 1 \mathrm{KFZ1} \cdot \mathrm{FZ1}-$ Ws $\cdot$ FP1/Z1

$\mathrm{dFP} 2 / \mathrm{dt}=\mathrm{Rdz} \cdot \mathrm{Dz} \cdot(\mathrm{FP} 1-\mathrm{FP} 2)(0.5 \cdot \mathrm{Z} \cdot \mathrm{Z2})+\mathrm{PRO} 2 \cdot \mathrm{FP} 2-\mathrm{KD} 2 \cdot \mathrm{FP} 2$ - KFZ2 $\cdot \mathrm{FZ2}$ $+W s \cdot F P 2 / Z 2+W s \cdot F P 1 / Z 2$

$\mathrm{dFP} 3 / \mathrm{d} t=\mathrm{Ws} \cdot \mathrm{FP} 2 / \gamma / \mathrm{Z3}-\mathrm{Wm} \cdot \mathrm{FP} 3 / \mathrm{Z3}-\mathrm{KD} 3 \cdot \mathrm{FP} 3 \mathrm{KDB} \cdot \mathrm{FP3}$

$\mathrm{dPP} 4 / \mathrm{dt}=\mathrm{Wm} \cdot \mathrm{FP} 3 / \mathrm{Z} 4-\mathrm{KD} 4 \cdot \mathrm{FP} 4-\mathrm{Wm} \cdot \mathrm{FP} 4 / \mathrm{ZA}$

Zooplankton phosphorus

$\mathrm{dFZ1} / \mathrm{dl}=\mathrm{KFZ1} \cdot \mathrm{FZ1}-\mathrm{KDFZ} \cdot \mathrm{KD} 1 \cdot \mathrm{FZ1}-\mathrm{KG} \cdot \mathrm{FZ1}-\mathrm{Ws} 3 \cdot \mathrm{FZ1} / \mathrm{Z1}$

$\mathrm{dFZ} / \mathrm{dl}=\mathrm{KFZ2} \cdot \mathrm{FZ2}-\mathrm{KDFZ} \cdot \mathrm{KD2} \cdot \mathrm{FZ2}-\mathrm{KG} \cdot \mathrm{FZ2}+\mathrm{Ws} 3 \cdot \mathrm{FZ1/Z2}-\mathrm{Ws} \cdot \mathrm{FZ} 2 / 22$ $\mathrm{dFZ} / \mathrm{dt}=-\mathrm{KDFZ} \cdot \mathrm{KD} 3 \cdot \mathrm{FZ} 3-\mathrm{KDFZ} \cdot \mathrm{KDB} \cdot \mathrm{FZ3}+\mathrm{Ws} 3 \cdot \mathrm{FZ2} / \mathrm{\gamma} / \mathrm{Z3}-\mathrm{Wm} \cdot \mathrm{FZ} 3 / \mathrm{Z3}$ $\mathrm{dFZ} / \mathrm{dl}=-\mathrm{KDFZ} \cdot \mathrm{KD} 4 \cdot \mathrm{FZ} 4+\mathrm{Wm} \cdot \mathrm{FZ} 3 / \mathrm{Z} 4-\mathrm{Wm} \cdot \mathrm{FZ} 4 / \mathrm{ZA}$

Sediment absorbed phosphorus

dEPA3/dt=-KEP・(EPA3-CP3/ $\alpha)$

$\mathrm{dBPR} 3 / \mathrm{dt}=\mathrm{KR} \cdot(\mathrm{EPR} 3-\mathrm{C} .3 \cdot \boldsymbol{\beta} \cdot \omega \cdot \mathrm{MO}) \cdot(\mathrm{CP} 3 /(\mathrm{CP} 3+\mathrm{CP} 30))$

$\mathrm{dEP} 4 / \mathrm{dt}=\mathrm{KEP} \cdot(\mathrm{EP} 4-\mathrm{CP} 4 / \alpha)$

Dissolved oxygen

$\mathrm{dCO} 1 / \mathrm{dt}=\mathrm{Dz} \cdot(\mathrm{CO} 2-\mathrm{CO}) /(0.5 \cdot \mathrm{Z} \cdot \mathrm{Z1})+\mathrm{Rop} \cdot \mathrm{PRO} \cdot \mathrm{FP1}$ Rop $\cdot \mathrm{KD} 1 \cdot \mathrm{FP} 1$ Roc $\mathrm{KDC} \cdot(\mathrm{COD1} 10.5)$ Roc $-\mathrm{RKD} \cdot \mathrm{KD1} \cdot \mathrm{PC1}$ ROP $-\mathrm{KDFZ} \cdot \mathrm{KD1} \cdot$ FZ1+LDO/SAZ1 KA $(\mathrm{CO} 1-\mathrm{COsa}) / Z 1-4.57 \cdot \mathrm{KCN} 1 \cdot \mathrm{CN1}+3.43 \cdot \mathrm{KN} 1 \cdot \mathrm{CNN}$ $\mathrm{dCO} / \mathrm{d} t=\mathrm{Dz} \cdot(\mathrm{CO} 1-\mathrm{CO} 2)(0.5 \cdot \mathrm{Z} \cdot \mathrm{Z2})+\boldsymbol{\gamma} \cdot \mathrm{Rdm} \cdot \mathrm{D} \cdot(\mathrm{CO} 3-\mathrm{CO} 2)(0.5 \cdot(\mathrm{Z2}+\mathrm{Z3}) \cdot$ $\mathrm{Z2})+\mathrm{Rop} \cdot \mathrm{PRO} 2 \cdot \mathrm{FP2} \mathrm{Rop} \cdot \mathrm{KD2} \cdot \mathrm{FP2}$ Roc $\cdot \mathrm{KDC} \cdot(\mathrm{COD} 2-0.5)$ Roc $\cdot \mathrm{RKD} \cdot$ $\mathrm{KD} 2 \cdot \mathrm{PC2}-\mathrm{Rop} \cdot \mathrm{KDFZ} \cdot \mathrm{KD} 2 \cdot \mathrm{FZ2}-\gamma \cdot \mathrm{Rop} \cdot \mathrm{KDB} \cdot \mathrm{FP} 3 \cdot \mathrm{Z3} / \mathrm{Z2}-\boldsymbol{\gamma} \cdot \mathrm{Rop} \cdot$ $\mathrm{KDFZ} \cdot \mathrm{KDB} \cdot \mathrm{FZ} 3 \cdot \mathrm{Z3} / 22-4.57 \cdot \mathrm{KCN} 2 \cdot \mathrm{CN} 2+3.43 \cdot \mathrm{KN} 2 \cdot \mathrm{CNN} 2$

$\mathrm{dCO} / \mathrm{dt}=\mathrm{Rdm} \cdot \mathrm{D} \cdot(\mathrm{CO} 4-\mathrm{CO} 3)(0.5 \cdot \mathrm{Z3} \cdot \mathrm{Zm})+\mathrm{Rdm} \cdot \mathrm{D} \cdot(\mathrm{CO} 2-\mathrm{CO} 3)(0.5 \cdot$

$(\mathrm{Z2}+\mathrm{Z3}) \cdot \mathrm{Z3})$-Rop $\cdot \mathrm{KD} 3 \cdot \mathrm{FP} 3$ Roc $\cdot \mathrm{RKD} \cdot \mathrm{KD} 3 \cdot \mathrm{PC} 3$ Rop $\cdot \mathrm{KDFZ} \cdot \mathrm{KD} 3 \cdot \mathrm{FZ} 3$ $4.57 \cdot \mathrm{KCN} 3 \cdot \mathrm{CN} 3+3.43 \cdot \mathrm{KN} 3 \cdot \mathrm{CNN} 3$

$\mathrm{dCO} / \mathrm{dt}=\mathrm{Rdm} \cdot \mathrm{D} \cdot(\mathrm{CO}-\mathrm{CO} 4)(0.5 \cdot \mathrm{ZA} \cdot \mathrm{Zm})$-Rop $\cdot \mathrm{KD} 4 \cdot \mathrm{FP} 4-\mathrm{Roc} \cdot \mathrm{RKD} \cdot \mathrm{KD} 4 \cdot$ $\mathrm{PC} 4-\mathrm{Rop} \cdot \mathrm{KDFZ} \cdot \mathrm{KD} 4 \cdot \mathrm{FZ} 4-4.57 \cdot \mathrm{KCN} 4 \cdot \mathrm{CN} 4+3.43 \cdot \mathrm{KN} 4 \cdot \mathrm{CNN} 4$ $\mathrm{dMO} / \mathrm{dt}=\mathrm{KMD} \cdot \mathrm{MO} \cdot \mathrm{CO} /(\mathrm{CO}+\mathrm{CO} 30)+\mathrm{RX} \cdot \mathrm{KMP} \cdot \mathrm{M} \cdot \mathrm{CO} /(\mathrm{CO}+\mathrm{CO} w)$ $\mathrm{dM} / \mathrm{dl}=\mathrm{KMD} \cdot \mathrm{MO} \cdot \mathrm{CO} /(\mathrm{CO}+\mathrm{CO} 30) \mathrm{RX} \cdot \mathrm{KMP} \cdot \mathrm{M} \cdot \mathrm{CO} 2 /(\mathrm{CO} 2+\mathrm{COw})$

\section{Organic nitrogen}

$\mathrm{dPNi} / \mathrm{d}=\mathrm{Rnp} \cdot \mathrm{FPi} \quad(\mathrm{i}=1 \sim 4)$

$\mathrm{NH}_{4}$ - nitrogen

$\mathrm{dCN} 1 / \mathrm{dl}=\mathrm{Dz} \cdot(\mathrm{CN} 2-\mathrm{CN} 1)(0.5 \cdot \mathrm{Z} \cdot \mathrm{Z1})-\mathrm{PRO} 1 \cdot \mathrm{Rcnl} \cdot \mathrm{FN1}+\mathrm{KD} 1 \cdot \mathrm{FN} 1+\mathrm{Rnp} \cdot$ $\mathrm{KDFZ} \cdot \mathrm{KD} 1 \cdot \mathrm{FZ1}-\mathrm{KCN1} \cdot \mathrm{CN} 1+0.5 \cdot \mathrm{LN} / \mathrm{SAZ1}$

$\mathrm{dCN} 2 / \mathrm{dt}=\mathrm{Dz} \cdot(\mathrm{CN} 1-\mathrm{CN} 2) /(0.5 \cdot \mathrm{Z} \cdot \mathrm{Z2})+\gamma \cdot \mathrm{D} \cdot(\mathrm{CN} 3-\mathrm{CN} 2)(0.5 \cdot(\mathrm{Z2}+\mathrm{Z3}) \cdot \mathrm{Z} 2)$ $\mathrm{PRO} 2 \cdot \mathrm{Rcn} 2 \cdot \mathrm{FN} 2+\mathrm{KD} 2 \cdot \mathrm{FN} 2+\mathrm{Rnp} \cdot \mathrm{KDFZ} \cdot \mathrm{KD} 2 \cdot \mathrm{FZ} 2+\gamma \cdot \mathrm{KDB} \cdot \mathrm{FN} 3 \cdot$ $\mathrm{Z3} / \mathrm{Z2}+\boldsymbol{\gamma} \cdot \mathrm{Rnp} \cdot \mathrm{KDFZ} \cdot \mathrm{KDB} \cdot \mathrm{Z} 3 / \mathrm{Z2}-\mathrm{KCN} 2 \cdot \mathrm{CN} 2$

$\mathrm{dCN} 3 / \mathrm{dt}=\mathrm{D} \cdot(\mathrm{CN} 4-\mathrm{CN} 3)(0.5 \cdot \mathrm{Z3} \cdot \mathrm{Zm})+\mathrm{D} \cdot(\mathrm{CN2}-\mathrm{CN} 3)(0.5 \cdot(\mathrm{Z2}+\mathrm{Z3}) \cdot \mathrm{Z3})+\mathrm{KD} 3 \cdot$ $\mathrm{FN} 3+\mathrm{Rnp} \cdot \mathrm{KDFZ} \cdot \mathrm{KD} 3 \cdot \mathrm{FZ3}-\mathrm{KCN} 3 \cdot \mathrm{CN} 3+(\mathrm{KEN} / \omega) \cdot(\mathrm{EN} 3-\mathrm{CN} 3 / \alpha)-\mathrm{Wm} \cdot$ $\mathrm{CN} 3 / \mathrm{Z3}$

$\mathrm{dCN} 4 / \mathrm{d}=\mathrm{D} \cdot(\mathrm{CN} 3-\mathrm{CN} 4)(0.5 \cdot \mathrm{ZA} \cdot \mathrm{Zm})+\mathrm{KD} 4 \cdot \mathrm{FN} 4+\mathrm{Rnp} \cdot \mathrm{KDFZ} \cdot \mathrm{KD} 4 \cdot \mathrm{FZ4}-$ $\mathrm{KCN} 4 \cdot \mathrm{CN} 4+(\mathrm{KEN} / \omega) \cdot(\mathrm{EN} 4-\mathrm{CN} 4 / \alpha)$

$\mathrm{NO}_{3}$ - nitrogen

$\mathrm{dCNN} 1 / \mathrm{dt}=\mathrm{Dz} \cdot(\mathrm{CNN} 2-\mathrm{CNN} 1) /(0.5 \cdot \mathrm{Z} \cdot \mathrm{Z1})-\mathrm{PRO} 1 \cdot \mathrm{Rcmn} 1 \cdot \mathrm{FN} 1+\mathrm{KCN} 1 \cdot \mathrm{CN} 1$ $-\mathrm{KN} 1 \cdot \mathrm{CNN} 1+0.5 \cdot \mathrm{LN} / \mathrm{SAZ} 1$

$\mathrm{dCNN} / \mathrm{dt}=\mathrm{Dz} \cdot(\mathrm{CNN} 1-\mathrm{CNN} 2) /(0.5 \cdot \mathrm{Z} \cdot \mathrm{Z2})+\gamma \cdot \mathrm{D} \cdot(\mathrm{CNN} 3-\mathrm{CNN}))(0.5 \cdot$ $(\mathrm{Z2}+\mathrm{Z3}) \cdot \mathrm{Z2})+\mathrm{PRO} 2 \cdot \mathrm{Renn} 2 \cdot \mathrm{FN2}+\mathrm{KCN} 2 \cdot \mathrm{CN} 2-\mathrm{KN} 2 \cdot \mathrm{CNN} 2$

$\mathrm{dCNN} 3 / \mathrm{dt}=\mathrm{D} \cdot(\mathrm{CNN} 4-\mathrm{CNN} 3)(0.5 \cdot \mathrm{Z3} \cdot \mathrm{Zm})+\mathrm{D} \cdot(\mathrm{CNN} 2-\mathrm{CNN} 3)(0.5 \cdot(\mathrm{Z2}+\mathrm{Z3}) \cdot$ $\mathrm{Z3})+\mathrm{KCN} 3 \cdot \mathrm{CN} 3-\mathrm{KN} 3 \cdot \mathrm{CNN} 3-\mathrm{Wm} \cdot \mathrm{CN} 3 / 23$

$\mathrm{dCNN} 4 / \mathrm{dt}=\mathrm{D} \cdot(\mathrm{CNN} 3-\mathrm{CNN} 4)(0.5 \cdot \mathrm{Z4} \cdot \mathrm{Zm})+\mathrm{KCN} 4 \cdot \mathrm{CN} 4-\mathrm{KN} 4 \cdot \mathrm{CNN} 4+\mathrm{Wm} \cdot$ CNN3/Z4-Wm・CNN4/Z4

Sediment absorbed nitrogen

$\mathrm{dEN} 3 / \mathrm{DT}=\mathrm{KEN} \cdot(\mathrm{EN} 3-\mathrm{CN} 3 / \alpha)$

$\mathrm{dEN} 4 / \mathrm{dt}=\mathrm{KEN} \cdot(\mathrm{EN} 4-\mathrm{CN} 4 / \alpha)$

COD

$\mathrm{dCOD} 1 / \mathrm{dt}=-\mathrm{KDC} \cdot(\mathrm{COD} 1-0.5)+\mathrm{Dz} \cdot(\mathrm{COD} 2-\mathrm{COD} 1) /(0.5 \cdot \mathrm{Z} \cdot \mathrm{Z1})+\mathrm{LCOD} / \mathrm{SA} \mathrm{Z} 1$ $\mathrm{dCOD} / \mathrm{dt}=\mathrm{KDC} \cdot(\mathrm{COD} 2-0.5)+\mathrm{Dz} \cdot(\mathrm{COD} 1-\mathrm{COD} 2)(0.5 \cdot \mathrm{Z} \cdot \mathrm{Z} 2)$

$\mathrm{TCOD} 1=\mathrm{COD} 1+(\mathrm{FP} 1+0.2 \cdot \mathrm{FZ1}) \cdot(143 / 3)+\mathrm{PC} 1$

TCOD2 $=$ COD2 $+(\mathrm{FP} 2+0.2 \cdot \mathrm{FZ} 2) \cdot(143 / 3)+\mathrm{PC} 2$

Detritus (COD)

$\mathrm{dPCl} / \mathrm{d} t=\mathrm{PRO} 1 \cdot \mathrm{FP} 1 \cdot \mathrm{Rpc} \cdot(\mathrm{Rop} / \mathrm{Roc}) \mathrm{RKD} \cdot \mathrm{KD} 1 \cdot \mathrm{PC} 1-\mathrm{W} \Omega \cdot \cdot \mathrm{PC} 1 / \mathrm{Z} 1$

$\mathrm{dPC} / \mathrm{dt}=\mathrm{PRO} 2 \cdot \mathrm{FP2} \cdot \mathrm{Rpc} \cdot(\mathrm{Rop} / \mathrm{Roc}) \mathrm{RKD} \cdot \mathrm{KD2} \cdot \mathrm{PC2}+\mathrm{W}_{2} \cdot \mathrm{PC1} / \mathrm{Z2}-\mathrm{Ws} \cdot$ $\mathrm{PC} 2 / 22$

$\mathrm{dPC} 3 / \mathrm{d}=\mathrm{Ws} 2 \cdot \mathrm{PC} / \mathrm{\gamma} / \mathrm{Z3}-\mathrm{RKD} \cdot \mathrm{KD} 3 \cdot \mathrm{PC} 3-\mathrm{Wm} \cdot \mathrm{PC} 3 / \mathrm{Z3}$

$\mathrm{dPC} 4 / \mathrm{d} t=\mathrm{RKD} \cdot \mathrm{KD} 4 \cdot \mathrm{PC} 4+\mathrm{Wm} \cdot \mathrm{PC} 3 / \mathrm{ZA}-\mathrm{Wm} \cdot \mathrm{PC} 4 / \mathrm{Z4}$

$\mathrm{PRO} 1=\mathrm{KP} 1 \cdot(\mathrm{CP} 1+\eta \cdot \mathrm{FP} 1)(\mathrm{CPO}+\mathrm{CP} 1+\eta \cdot \mathrm{FP} 1)$ (a)

$\mathrm{PRO}=\mathrm{KP1} \cdot(\mathrm{CN} 1+\eta \cdot \mathrm{FN} 1)(\mathrm{CNO}+\mathrm{CN} 1+\eta \cdot \mathrm{FN} 1)$ (b) (less value adopted)

LP, LDO, LN, LCOD : Input loadings from outside, SA: Surface area $\mathrm{Z}$ : Total depth of water layer $(=\mathrm{Z1}+\mathrm{Z2})$

$\mathrm{Zm}$ : Total depth of sediment layer $(=\mathrm{Z3}+\mathrm{Z4})$.
及び夏季の $\mathrm{T}-\mathrm{P}$ の平面分布形状等を考虑して, 平 面的には， 8 分割，鉛直的には，夏期の成属状況を 考慮して上層を平均水面下 $5 \mathrm{~m}$, 下層をそれ以潹と した. さらに，底泥の分割は表層 $1 \mathrm{~cm}$ ，下層 $4 \mathrm{~cm}$ の 2 層とした．計算の対象時期は 1987 年である.

Fig.1 は瀬戸内海のボックス分割とその諸元を示す.

\section{a) 流動予測モデル}

本計算に用いた流動モデルは，鉛直方向に静水圧 分布を仮定し, ナビエストークスの方程式及び連続 方程式を水深方向に平均化した 2 次元 2 層の差分形 メッシュモデルによった. 潮流計算を行った結果か ら流動の再現性や流量収支を検討した上で，恒流成 分とし, 8 Box 2 層の断面移流及び拡散流量を求 めた (詳細は文献" 参照)。

b) 水・底䨘予測モデル

水・底質モデル（以下 WSQM( Water-Sediment
Quality Model) という) は, 栄養塩から生産された プランクトンがテトリタスとして底泥に移行し，底 泥表面での酸素消費により底泥と水層との間に生じ る栄養塩の授受を定式化し，水質濃度の季節変化を 再現することを目的とした生態系モテルである.こ のモデルはこれまでに浮田ら ${ }^{6)}$ "7によよって 1 ボック ス多層のモテルの原型が提案されているが, 今回瀬 戸内海の多ボックスモテルに適用するにあたって灌 間の流動条件の再現，高次生物項の導入による生態 系の拡張, 硝化・眖窒メカニズムの導入などの改良 を加えた. 水・底質モテルの構成は Fig. 2 に示した ように $\mathrm{P} ， \mathrm{D} \mathrm{O}, \mathrm{N}, \mathrm{C} O \mathrm{O}$ Dのサブモデルであるが, $\mathrm{P}$ とD Oのモデル化が中心である．水層と底泥中の $\mathrm{P}$ は有機馝 $\mathrm{P}$ と無機態 $\mathrm{P}$ （C P ）に区別しており， 有機獎 $\mathrm{P}$ は植物プランクトン（F P ） と高次生物 （F Z ）を想定している，なお，高次生物には動物 
Table 2 Initial value of main parameters and coefficients in the WSQM.

\begin{tabular}{|c|c|c|c|c|c|c|c|}
\hline Label & Component & Initial value & Unit & Label & Component & Initial value & Unit \\
\hline $\mathrm{CPi}$ & Inorg $P$ conc. in $i$ th water layer $(i=1,2)$ & $0.01,0.03$ & $\mathrm{mg} / \mathrm{l}$ & KEP & Adsorption/desorption rate coefficient & 0.0001 & $\overline{1 / \mathrm{sec}}$ \\
\hline $\mathrm{CPj}$ & Inorg $P$ conc. in $j$ th sediment layer $(j=3,4)$ & $0.2,2.0$ & $\mathrm{mg} / \mathrm{l}$ & KR & Precipitation or dissolving rate coefficient & 0.00001 & $1 / \mathrm{sec}$ \\
\hline FPi & Org $P$ conc. in $i$-th water layer & $0.03,0.02$ & $\mathrm{mg} / \mathrm{l}$ & KMP & Production rate coefficient of 'MO' & 0.30 & $1 /$ day \\
\hline FPj & Org $P$ conc. in $j$-th sediment layer & $10.0,2.0$ & $\mathbf{m g} / \mathbf{l}$ & KMD & Diminishing rate coefficient of 'MO' & 0.30 & $1 /$ day \\
\hline FZi & Zooplankton $P$ conc. in i-th water layer & 0.0005 & $\mathrm{mg} / \mathrm{l}$ & KA & Reaeration rate coefficient & $191 \sim 517$ & $\mathrm{~cm} /$ day \\
\hline $\mathbf{F Z j}$ & Zooplankton $P$ conc. in $j$ th sediment layer & $0.2,0.002$ & $\mathrm{mg} / \mathrm{l}$ & $\mathrm{CDz}$ & Base value of vertical mixing coefficient & $0.5 \sim 1.5$ & $\mathrm{~cm}^{2} / \mathrm{sec}$ \\
\hline EPA & Adsorbed $\mathrm{P}$ conc, in the upper sediment layer & 0.8 & $\mu \mathrm{g} / \mathrm{gdry}$ & D & Diffusion coefficient in sediment layer & 0.432 & $\mathrm{~cm}^{2} /$ day \\
\hline EPR & Stored $\mathrm{P}$ conc. in the upper sediment layer & 9.2 & $\mu \mathrm{g} / \mathrm{gdry}$ & Ws & Settling velocity of 'FP' & $10 \sim 25$ & $\mathrm{~cm} /$ day \\
\hline EPj & Adsorbed $P$ conc. in $j$ th sediment layer & 10.0 & $\mu \mathrm{g} / \mathrm{gdry}$ & Ws2 & Settling velocity of 'PC' & 5.0 & $\mathrm{~cm} /$ day \\
\hline $\mathrm{CNi}$ & Inorg-N conc. in $\mathrm{i}$-th water layer & $0.2,0.4$ & mg/l & Ws3 & Settling velocity of 'FZ' & $7.5 \sim 30.0$ & $\mathrm{~cm} /$ day \\
\hline $\mathrm{CNj}$ & Inorg- $\mathrm{N}$ conc. in $\mathrm{j}$-th sediment layer & $2.0,5.0$ & $\mathbf{m g} / \mathbf{l}$ & Wm & Sedimentation rate of sediment layer & 0.002 & $\mathrm{~cm} /$ day \\
\hline FNi & Org-N conc. in $\mathrm{i}-\mathrm{th}$ water layer & $0.6,0.4$ & $\mathrm{mg} / \mathrm{l}$ & COsat & Saturated DO concentration & $7.0 \sim 10.0$ & $\mathrm{mg} / \mathrm{l}$ \\
\hline $\mathrm{ENj}$ & Adsorbed $-\mathrm{N}$ conc. in $\mathrm{j}$ th sediment layer & $8.0,20.0$ & $\mu \mathrm{g} / \mathrm{gdry}$ & CPO & Michaelis constant of 'CP' for $\mathrm{KP}$ revising & 0.01 & mg/l \\
\hline CODi & Alochtonus COD conc. in i-th water layer & 1.0 & $\mathrm{mg} / \mathrm{l}$ & $\cos 3$ & Michaelis constant of 'DO' in $\mathrm{Z1}$ & -10.0 & $\mathrm{mg} / \mathrm{l}$ \\
\hline PCi & Detritus COD conc. in i-th water layer & 0.0 & $\mathrm{mg} / \mathrm{l}$ & COw & Michaelis constant of 'DO' in $\mathrm{Z3}$ & 1.0 & $\mathrm{mg} / \mathrm{l}$ \\
\hline Mo & Oxidized layer density in the upper sediment & 200.0 & $\mathrm{mg} / \mathrm{l}$ & $\alpha$ & Adsorption equivalent constant & 0.25 & $\mathrm{~g} / \mathrm{ml}$ \\
\hline $\mathbf{M}$ & Reduced layer density in the upper sediment & 200.0 & $\mathrm{mg} / \mathrm{l}$ & $\omega$ & Volume/weight ratio of interstitial water/dry mud & 1.6 & $\mathrm{ml} / \mathrm{g}$ \\
\hline $\mathrm{COi}$ & Dissolved oxygen conc. in i-th water layer & $9.0,9.0$ & $\mathbf{m g} /$ & $\beta$ & Activity of oxidized layer for P storing & 0.1 & \\
\hline $\mathrm{CO}$ & Dissolved oxygen conc. in $\mathrm{j}$-th sediment layer & $0.0,-10.0$ & mg/l & $\boldsymbol{\gamma}$ & Porosity of sediment & 0.78 & \\
\hline KP1 & Production rate coefficient of 'FP1' & $0.44 \sim 5.48$ & $1 /$ day & $\eta$ & Availability of org-N, $\mathrm{P}$ for production & 0.01 & \\
\hline $\mathrm{KDi}$ & Decomposition rate coefficient of 'FPi' & $0.32 \sim 0.66$ & $1 /$ day & Rdm & Revising factor of $\mathrm{D}$ for ' $\mathrm{CO}$ ' to that for ' $\mathrm{CP}$ ' & 3.0 & \\
\hline $\mathrm{KDj}$ & Decomposition rate coefficient of 'FPj' & $0.001 \sim 0.11$ & $1 /$ day & Rop & Conversion factor Oxygen/P & 109.5 & \\
\hline $\mathrm{KDB}$ & Decomposition rate coefficient by benthos & 0.001 & $1 /$ day & Ron & Conversion factor Oxygen/N & 15.1 & \\
\hline $\mathrm{KN}$ & Denitrification rate coefficient & 0.2 & $1 /$ day & Roc & Conversion factor Oxygen/COD & 3.0 & \\
\hline $\mathrm{KCN}$ & Nitrification rate coefficient & 0.1 & $1 /$ day & Rpc & Ratio of 'PC'production to 'FP' production & 0.01 & \\
\hline $\mathrm{KDC}$ & Decreasing rate coefficient of COD & 0.02 & $1 /$ day & RKD & Revising factor of KDi for 'FP' to that for 'PC' & 0.03 & \\
\hline KFZ & Increasing rate coefficient of FZ & 0.30 & $1 /$ day & RX & Seasonal revising factor of KMP & $0.3 \sim 1.7$ & \\
\hline
\end{tabular}

プランクトンの他，より高次の魚等も含めている. さらに，表層泥において P の吸脱着特性を表現する ため, 酸化層 (MO) の消長に伴い可溶化, 不可溶 化する鉄態 $P$ に対応する反応型吸着㦔 $P$ (E P R) と, 間隙水と底泥粒子との間の吸着平衡を想定した 吸着態P（E P A ）に分けている，下届泥において は吸着態 $P(E P)$ のみである.これらの消長と $E$ P Rの季節変化の模式図を Fig. 3 に示す. また，C O D モテルは陸由来負荷によるもの，F P から換算 して求めた一次生産によるものとテトリタスような C OD蓄稓項（PC） との和で表している．Nに関 しては，Pモテルと大体同じであり，有機態 N（F $\mathrm{N}$ ）は $\mathrm{P}$ から換算して求める. 無機態 $\mathrm{N}(\mathrm{CN})$ は $\mathrm{NH}_{4}-\mathrm{N}$ と $\mathrm{NO}_{3}-\mathrm{N} に$ 分けてある. その他, 吸着 態 $N(E N) ，$ 還元層（M）を設けている. 本モテ ルの基礎式を Table 1 に，計算に用いたパラメータ 値を Table 2 にそれぞれ示す．計算はルンゲ・クッ 夕法によった. モデルに用いたパラメータは浮田 ${ }^{7}$ と山田 ${ }^{10)}$ を参考にして定めたが，重要な係数につ いては感度解析により検討し若干の変更を行った. c）モデルの強制関数

モテルの強制関数としては，Table 3 に示したよ うに水質瀑度の铅直湿合と日射及び水温などを与え た. 日射においては，日射による照度効果 ${ }^{11)}$ と瀬

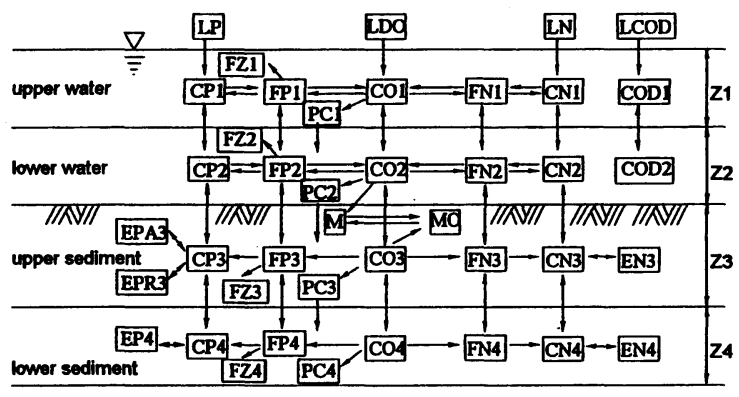

Fig. 2 Schematic view of the WSQM.

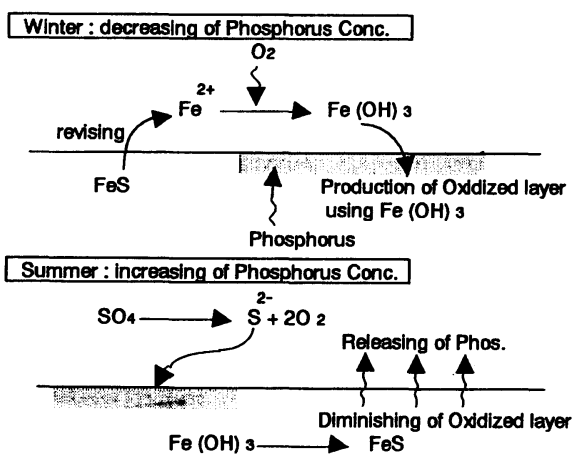

Fig. 3 Diagram of seasonal variation for EPR. 
Table 3 Forced functions in the WSQM.

$$
\begin{aligned}
& \text { (1) Vertical mixing } \\
& Q z=A \cdot \frac{D z}{0.5 \cdot\left(z_{u}+z_{l}\right)} \\
& \text { (2) Light intensity } \\
& \text { light }=390+170 \cdot \sin \left(\frac{2 \pi}{365} \cdot(\text { day }-80)\right)
\end{aligned}
$$

(3) Water temperature

$$
\begin{aligned}
& T 1=17.63+8.52 \cos \left(\frac{2 \pi}{365}(\text { day }-219)\right) \\
& T 2=16.46+7.73 \cos \left(\frac{2 \pi}{365}(\text { day }-222)\right)
\end{aligned}
$$

(4) Vertical mixing coefficient

$$
\begin{aligned}
& \text { if , day } \leq 74 \quad D z=1.440 \cdot c d z \\
& 74 \leq \text { day }<192 \quad D z=\left(1.6-\frac{(d a y-103)^{2}}{5442.0}\right) \cdot c d z \\
& 192 \leq \text { day }<266 \quad D z=\left(0.1+\frac{(\text { day }-207)^{2}}{3628.0}\right) \cdot c d z \\
& 266 \leq \text { day }<290 \quad D z=\left(1.440-\frac{(\text { day }-290)^{2}}{1158.7}\right) \cdot c d z \\
& 290 \leq \text { day } \quad D z=1.440 \cdot c d z
\end{aligned}
$$

戸内海の気象資料 ${ }^{8)}$ を基にして，調和解析により正 弦曲線を得た. 水温については環境庁の観測值 ${ }^{12)}$ 調和解析して季節変化曲線を求めた．なお，底泥の 水温は水層より 30 日遅らせて変化するようにした. また, 5 年毎の原単位計算により得た 1957 ～ 1987 年 ( 30 年間) の流入負荷量の計算結果 ${ }^{13)}$ 古強制関 数として与えた（Fig.4）.

\section{（2）モデルの検証}

\section{a）水䨘漕度の季節变化}

Fig. 5 は瀬戸内海の上層の C O D と下層の D O 灌 度の季節変化の計算結果を示しているか， C O Dの 場合, 瀬戸内海全域で, 7 月下旬頃から 8 月にかけ て䓹度が高くなり，秋季から大きく下がっている. 特に，大阪湾を中心に瀬戸内海の東部海域が西部海 域より濃度が高い傾向が見られる．下層のDOにつ いては，8月をピークとした夏場のD O低下がよく 再現されている. Fig. 6 は比較的水質データの入手 しやすい大阪湾 ${ }^{14)}$ について水質浱度の季節変化の
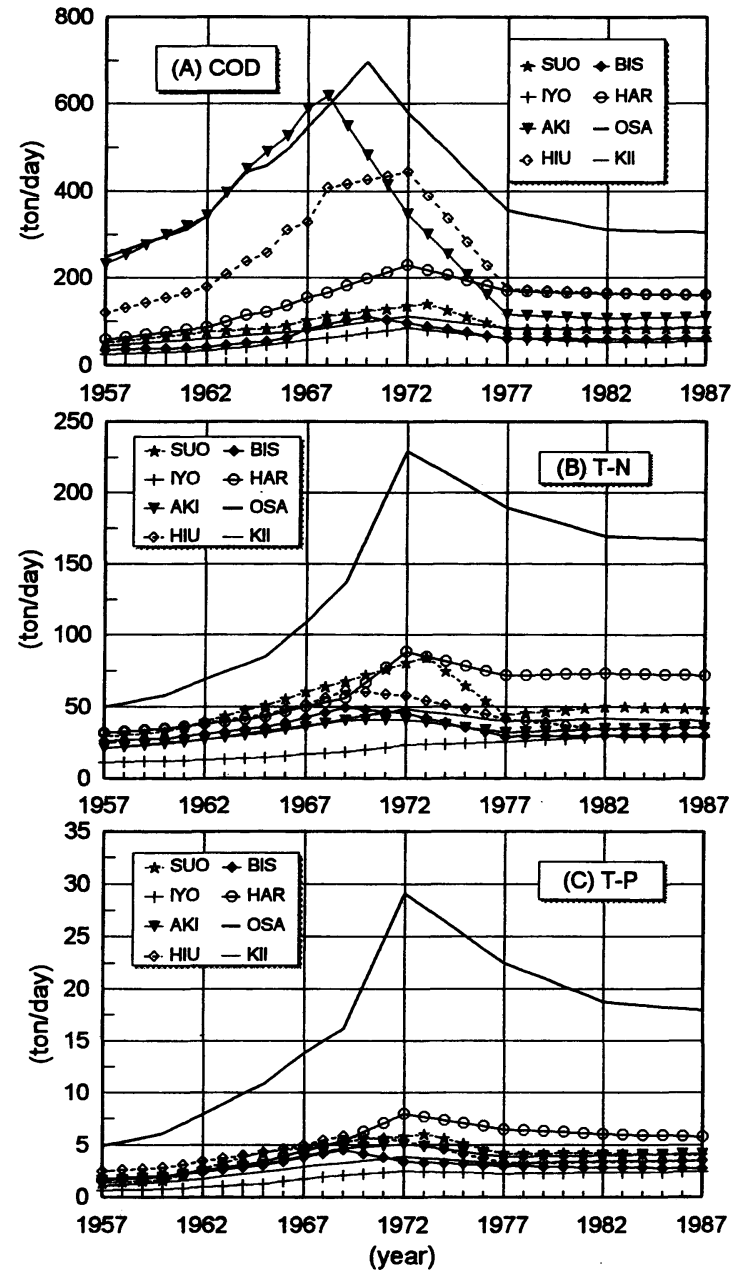

Fig. 4 Annual variation of pollutant loads in Seto-Inland Sea.
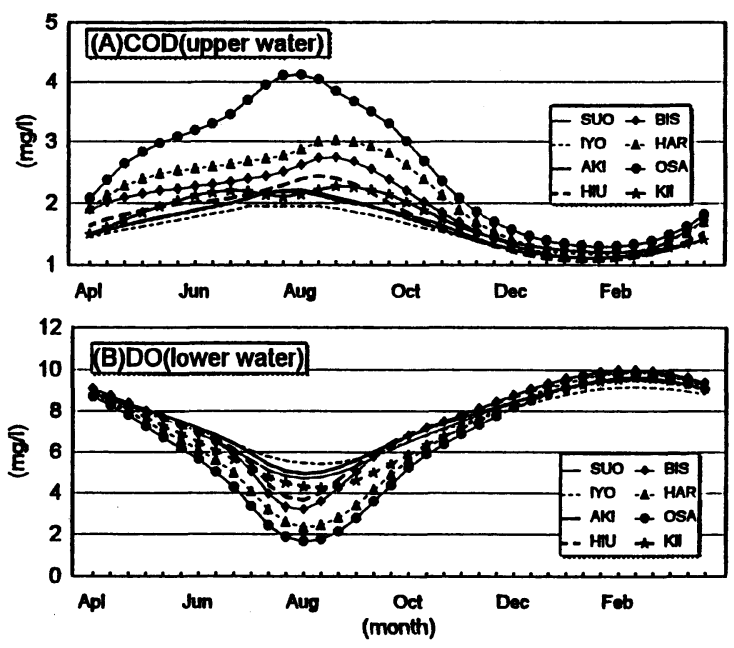

Fig. 5 Computed reaults of the seasonal variation for water quality in Seto-Inland Sea.. 


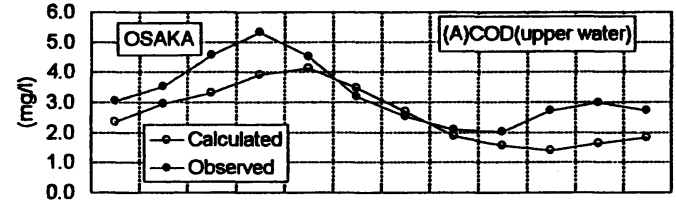

Ap! May Jun Jul Aug Sep Oct Nov Dec Jan Feb Mar

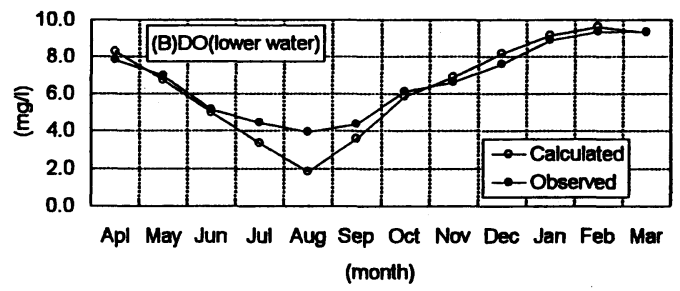

Fig. 6 Comparison between calculated value and observed value of the seasonal variation for $C O D, D O$ in Osaka Bay.

再現性について検証した結果を示している. 図を見 ると，CODについては濃度のピークが実測值より 1 カ月逢れて現れているが, 秋口の濃度の減少傾向は ほぼ再現できていると思われる．下層のDOについ ても，8月の貧酸素の最低濃度がやや翼なっている が, 全体的には, 夏場の D O 低下や季節変化が再現 できている.

\section{b) 年平均水兵漊度の検証}

水質濃度の検証のために必要な，実測に基づく検 証用資料としてＣＯD，DOについては，環境庁 ${ }^{12) ，}$ 栄養塩については, 水産庁 ${ }^{15)}$ の資料を用いた. これ らは, 海域の数ポイントを調査したものである.こ れらのポイントの水質濃度值に，それぞれ水深によ る重みを乗じて灌ごとに体積平均する事により, 年 平均濃度を得た。なお，上記の資料には，高次生物 濃度のデー夕は含まれていない. 門谷・岡市ら ${ }^{16)} に$ よると，大阪湾，播磨灘において，T Pのうち, 動 物プランクトン㮩 $\mathrm{P}$ の占める割合は, 大阪湾の場合, 1. $2 \%$ ，播磨灘は $1.8 \%$ としている．これより 本モテルでは全淎において, 魚を含めたものとして T Pの 2 \%を高次生物態 P みみる. 以上のようにし て求めた実測值之計算結果の比較を C O D, D O, 高次生物㦔 $P$ (F Z ) について Fig. 7 に示した. 計 算値は当該年度における毎日計算濃度を年平均した ものである. まず，上層のＣＯD濃度については， 図に見られるように，紀伊水道を除いた灘において 実測值にほぼ一致している. 下届のDO漕度につい ても全灌においてよく実測值を再現している．上層 のF Z 浱度の計算結果はおおむね実測值に近いレベ

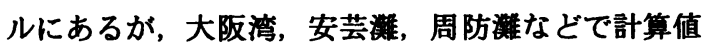
が高めとなっている.
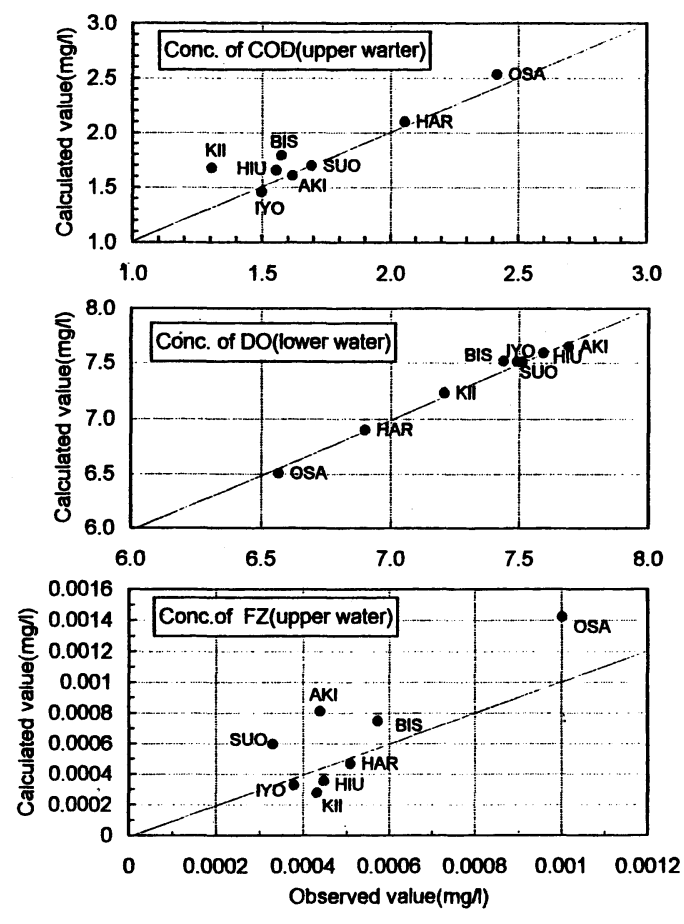

Fig. 7 Verifications of water quality in Seto-Inland Sea.

\section{3.モデルによる水筫理の検討}

\section{（1）水貫濼度の経年変的}

1957 年から 1987 年までの毎年の流入負荷量を与 えて, この期間の水質濃度の経年変化を算出した. なお，計算開始時の最初の 5 年間は 1957 の負荷量 を与え続け，初期状態を安定させた. 上層のＣOD と下属の D O濃度についての経年変動計算結果を Fig. 8 に示す. 左右の図を比較して見ると瀬戸内海 の東部海域の方が西部海域よりも，上届のＣＯDと 下層のDＯともに，水質の経年変動が大きい傾向が 見られる.これは，Fig. 4 に示している負荷量の経 年変動と重ねて見ると, 計算結果によるCOD，D ○ともにピークや形状が負荷量によく対応している のがわかる. 流入負荷量がピークとなる 1972 年前 後は，計算においても水質のＣＯDがピーク，下層 水が最も貧酸素状節となっており，水質が最も悪い 時期といえる. 1965 1975 年における負荷量の減 少は，計算においてもCODの減少や下層のDＯ濃 度の上昇といった水質改善に反映していることが分 かる. それ以降の負荷の横ばいないし渐增も計算に よく対応している，多くの䧽では，CODと T P, T Nの負荷量のピークが同じ年にあり，このような 灘は計算水質濃度のピークもその年に見られる.し 

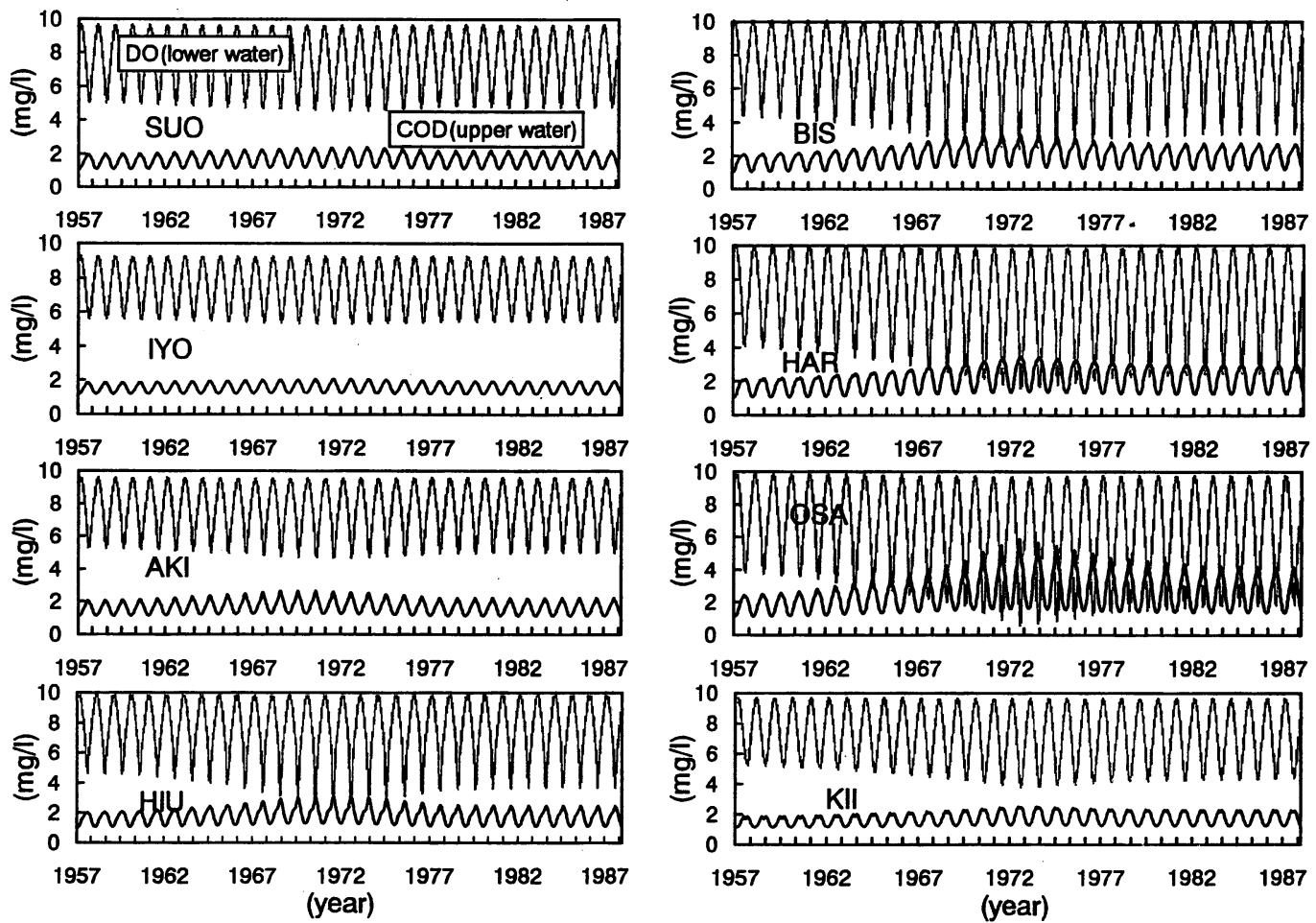

Fig. 8 Computed results of annual variation for COD, DO by using the WSQM.

かし，大阪湾，安芸淎のように負荷量において C O Dのピーク時が過ぎても，その後にT P・T Nのピ 一クがある灘は，後者のピーク時まで計算水質濃度 は悪化し続ける．このように水質に対して，COD 負荷の他に，栄養塩の影幚が大きいことが分かる.

\section{（2）灌別の負荷量と水䨢湌度との応答特性}

Fig. 9 はCOD, 窒素, リン及びT O D 経年負 荷量と水質濃度を対応したものを示す．なお，水質 洤度は経年計算值の年平均であり， T O D の経年負 荷量の推定は Fig. 4 の負荷量データから中西ら ${ }^{17)}$ によって提案している次の式 (1)により換算したも のを用いた.

$\mathrm{TOD}=3 \times \mathrm{COD}+(19.7 / 2) \times \mathrm{TN}+(143 / 2) \times \mathrm{TP}$

図をみると，周防灘はＣＯD負荷量の上昇に対し， C O D浱度は約 2 ppmになるまでは急激に悪化す るが，それ以上は，上昇勾配が小さくなっている. また, 1972 年以降, 負荷が減少しても, 水質回復 はさらに纊くなっている．よって周防灘は，COD が $1.6 \mathrm{ppm}$ を越えると，その回復には大幅な負荷削 減対策を要するといえる. 伊予灘は, 負荷の減少が, 忠実に，水質改善につながっており，比較的容易に 水質改善が可能な海域と言える．安芸鹳は，1965 年からの急激かつ大幅な C O D負荷削減がなされた

にもかかわらず，1972年までは全く水質が改善さ れなかった．これは，一方でT P $\mathrm{P} T \mathrm{~N}$ 負荷がこの 年まで渐増を続けていたのが原因である．1973 年 からの T P 負荷削減がなされると，水質はこれに対 応して改善されはじめた. 安芸敞の水質改善には, C O D 負荷より T P 負荷削減のほうが有効であった

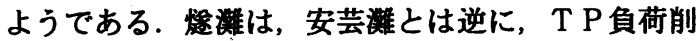
减後もCOD負荷が減らないうちは水質は改善され ていない，備鿁瀬戸は，1969 年の T P 負荷削減後 も 1970 年のC O D負荷削減後も水質は改善されず,

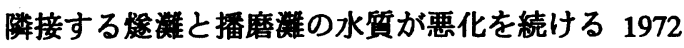
年まで, 同様に悪化している. また, この㵶は, 負 荷が小さいわりには㥞灘や播磨灘なみに水質が悪い。 これらのことから，備讃瀬戸の水質は，隣接する焙 灘，播磨灘との水交換により左右され易いと言える. 播磨灘は，C O D， T Pいずれの負荷についても， 線形的に水質が改善されており，バランスのとれた 負荷削減がなされているようである．大阪湾は， 1971 年以降 C O D負荷が削减されても，一方で T $\mathrm{P}$ 負荷が上昇していたため, 水質が全く改善されて おらず，むしろ T P負荷の上昇に合わせて，水質が 要化していた. よって, 大阪沙も安芸灘同様に， $\mathrm{T}$ P負荷の削減の方がC O D負荷削減よりも効果があ るようである. 紀伊水道は伊予䍩同様, 比較的水質 が良い海域であり，㑯向もよく似ていて，負荷に対 


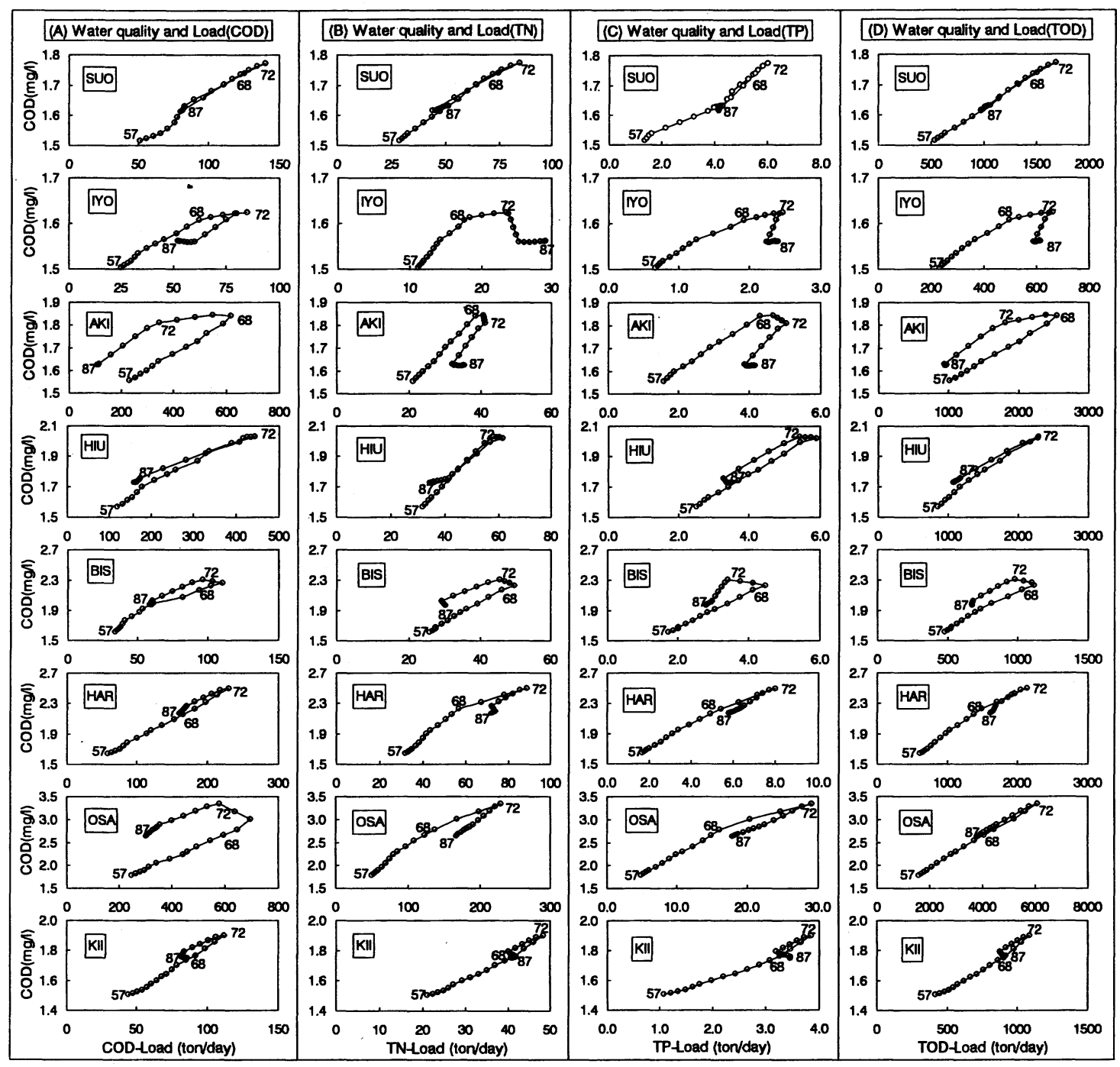

Fig. 9 Response between COD concentration and load of COD, TP, TN and TOD in Seto-Inland Sea(1957 1987).

\section{して順調に水質が改善されている.}

検討結果をまとめると，負荷量の増減は，水質濃 度に反映している。しかし,これはCODやPの負 荷に左右されるものではない，これは，大阪湾や安 芸灘に見られるように，CODを削减しても，リン の削減がない間は水質は改善されないことから明か である. また, 灘によっては負荷に対する水質の対 応が異なるようである.よって，水質改善の為の負 荷削減対策には，COD負荷だけでなく総合的な負 荷の削減が不可欠である. 城 ${ }^{18)}$ によると 1970 年代 以降の 10 年間に瀬戸内海全域の年平均值で上層と 下層ともに $\mathrm{N} / \mathrm{P}$ 比が 5 程度増加した報告がある. これは，各淎の特性にあった方法による負荷量の削 減や環境基準の設定が大切であることを表わしてい る. 近年, 排水中のリンの除去やリンを含む合成洗
用の使用禁止などにより，海域のリン嶩度が抑制さ れてきている. 一方, 公素の除去は技術的に難しく， 進んでいない，このために， N/P 比を考虑した T ODの環境基準の設定も含める必要があると考えら れる.

\section{（3）適正流入負荷量の検討}

\section{a）負荷旦削減の効果}

モテルよる具体的な陸域負荷量の削減について検 討した. 瀬戸内海で陸域から流入する負荷量を全域 で現状の $50 \%$ あるいは $100 \%$ 削减した時, さらに 窒素, リン, 及びC $\mathrm{OD}$ のそれぞれのみ削減した時 の, 大阪湾の上層の C O D 灌度の計算結果を Fig. 10 に示す. Fig. 10 により，CODのみの負荷量削 減の効果はまったく見られず, 全体にT Pのみなら 

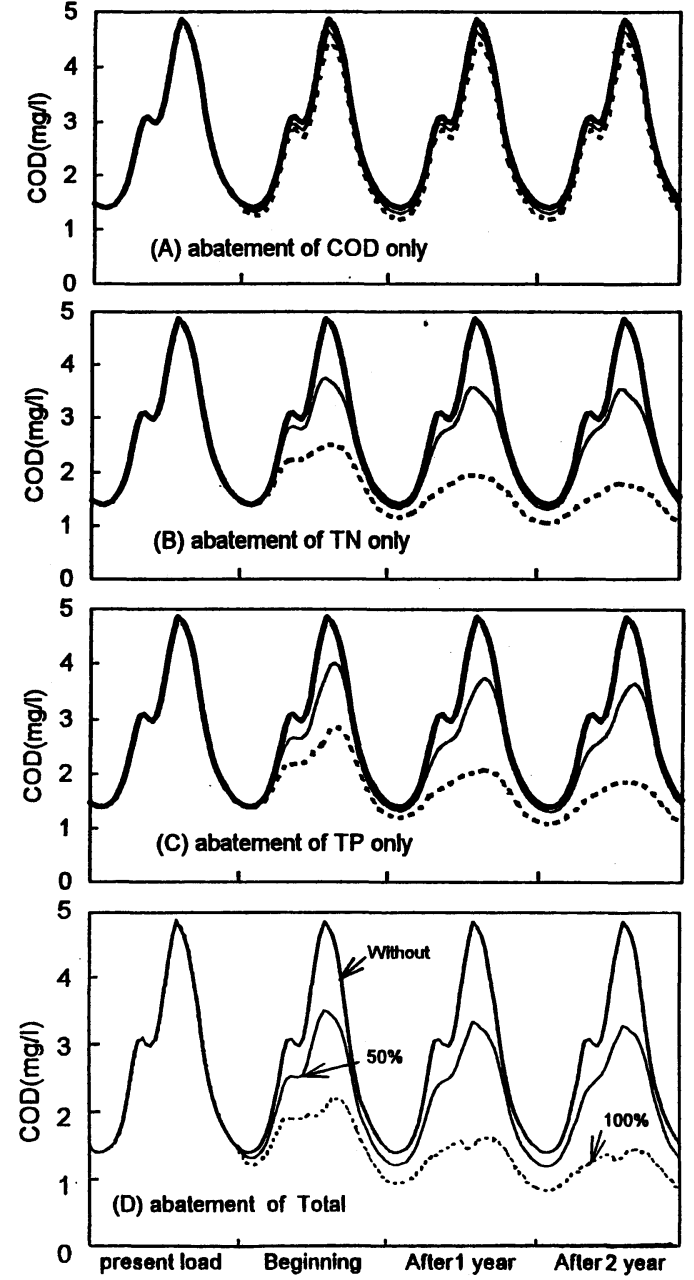

Fig. 10 The effect of loading abatement calculated by using the WSQM at the upper water in Osaka Bay.

ずTNの負荷削減の影響が大きいことがわかる．ま た, 負荷量削減の効果が安定するまでには約 2 年を 要すると考えられる.なお，負荷量を 50 \% 削堿し た結果がかならずしも $100 \%$ 削減と削减なしの平均 値をとろわけではないことから，水質嶩度と負荷量 の関係に非線形性が存在することが示唆される．た だし，現状において，より水質の良好な瀬戸内海西 部海域では負荷量と水質浱度はほぼ線形関係と認め られた. 上述のように, 負荷量削减の効果はこのモ テルの入力となる負荷量データを変更することによ り評価することができるが，ここではより簡単に負 荷量削减の効果を概算する方法を示す. Table 4 は 水・底質モテルを用い，各淎の T Nと T P の流入負 荷量をすべて 0 とした場合の水質灌度を基底濼度

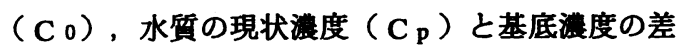
を人為濃度 $\left(\mathrm{Ca}_{\mathrm{a}}\right)$ とし，これに対する各鹳の寄与 率を算定したものである．水質の現状湌度（ $\mathrm{C}_{\mathrm{p}}$ )
Table 4 The degree of influence between water quality and arbitrated loads in each BOX.

\begin{tabular}{|c|c|c|c|c|c|c|c|c|c|}
\hline & TN(mgA) & suo & IYO & AKI & HIU & BIS & HAR & OSA & KII \\
\hline \multirow{3}{*}{ C } & $c_{p}$ & 0.20 & 0.17 & 0.21 & 0.21 & 0.30 & 0.26 & 0.59 & 0.25 \\
\hline & $C_{0}$ & 0.11 & 0.11 & 0.11 & 0.11 & 0.10 & 0.11 & 0.11 & 0.12 \\
\hline & $\mathrm{Ca}$ & 0.09 & 0.06 & 0.10 & 0.11 & 0.20 & 0.15 & 0.48 & 0.13 \\
\hline \multirow{9}{*}{$\lambda$} & suo & 0.59 & 0.27 & 0.10 & 0.04 & 0.01 & 0.00 & 0.00 & 0.00 \\
\hline & YYO & 0.11 & 0.18 & 0.08 & 0.03 & 0.01 & 0.00 & 0.00 & 0.00 \\
\hline & AKI & 0.12 & 0.22 & 0.33 & 0.16 & 0.05 & 0.02 & 0.01 & 0.01 \\
\hline & HIU & 0.11 & 0.19 & 0.29 & 0.44 & 0.12 & 0.04 & 0.02 & 0.03 \\
\hline & BIS & 0.03 & 0.06 & 0.08 & 0.14 & 0.35 & 0.14 & 0.05 & 0.08 \\
\hline & HAR & 0.02 & 0.04 & 0.06 & 0.09 & 0.22 & 0.38 & 0.15 & 0.25 \\
\hline & OSA & 0.02 & 0.03 & 0.05 & 0.08 & 0.20 & 0.35 & 0.73 & 0.48 \\
\hline & KII & 0.00 & 0.01 & 0.01 & 0.02 & 0.04 & 0.07 & 0.04 & 0.15 \\
\hline & $\mathrm{TP}(\mathrm{mg} / \mathrm{s})$ & suo & YYo & AKI & HIU & BIS & HAR & OSA & KII \\
\hline \multirow{3}{*}{ C } & $C_{p}$ & 0.021 & 0.019 & 0.020 & 0.023 & 0.025 & 0.031 & 0.048 & 0.029 \\
\hline & Co & 0.019 & 0.019 & 0.019 & 0.018 & 0.017 & 0.016 & 0.016 & 0.017 \\
\hline & $\mathrm{Ca}$ & 0.002 & 0.000 & 0.002 & 0.005 & 0.009 & 0.015 & 0.032 & 0.012 \\
\hline \multirow{8}{*}{$\lambda$} & suo & 0.54 & 0.24 & 0.08 & 0.04 & 0.01 & 0.00 & 0.00 & 0.00 \\
\hline & YYo & 0.10 & 0.16 & 0.06 & 0.03 & 0.01 & 0.00 & 0.00 & 0.00 \\
\hline & AKI & 0.16 & 0.27 & 0.37 & 0.19 & 0.05 & 0.02 & 0.01 & 0.01 \\
\hline & HIU & 0.12 & 0.18 & 0.28 & 0.42 & 0.12 & 0.04 & 0.02 & 0.03 \\
\hline & BIS & 0.03 & 0.06 & 0.08 & 0.14 & 0.32 & 0.12 & 0.04 & 0.07 \\
\hline & HAR & 0.02 & 0.03 & 0.05 & 0.07 & 0.19 & 0.31 & 0.12 & 0.19 \\
\hline & OSA & 0.03 & 0.05 & 0.07 & 0.10 & 0.27 & 0.45 & 0.78 & 0.58 \\
\hline & KIII & 0.00 & 0.01 & 0.01 & 0.01 & 0.03 & 0.06 & 0.03 & 0.12 \\
\hline
\end{tabular}

は㻴境庁 ${ }^{12)}$ の $1984 \sim 1987$ 年の 4 年平均した $\mathrm{T} \mathrm{N}$, T P の観測点分布図と，その分布図を瀬戸内海の水 梁，標高図 ${ }^{8)}$ に重ね合わせ，その浱度毎の分布面榬 を測定し各灘の現状濃度とした，TNで見ると，周 防灘 (SUO) の人為濃度に対する各灘の負荷寄与率 は，周防灌 $59 \%$ ，伊予灘 $11 \%$ ，安芸灘 $12 \%$ であ る. また，大阪湾の負荷は䇬接灌の影響度が大きい ことを示している.この表を用いれば，式 (2)によ り負荷削減後の水質濃度を概算することができる.

$$
\mathrm{C}_{\mathrm{b}}=\Sigma\left((1-\delta) \cdot \lambda_{i}\right\} \cdot \mathrm{C}_{\mathrm{a}}+\mathrm{C}_{0}
$$

ここで， $\mathrm{C}$ b は負荷削堿後の水質濃度， $\delta$ は灌毎負 荷削減率， $\lambda i$ は政毎負荷寄与率， $\mathrm{C}$ a は人為瀑度 C oは基底濼度を示す. すちろん，先述したように 厳密には負荷量と水質灌度の関係は線形とは言えな いので,この表から得られる水質峧度はあくまで目 安であり，より正確にはモテルの陸域からの負荷量 を変えて直接計算を行う必要がある点には注意して おく必要がある.

\section{b）適正流入負荷量の推算}

過去瀬戸内海では，マダイやサワラなどの高価格 の魚介類が豊かであったが，近年ではそれらの豊度 が低下し，一部が姿を消すなかで，カタクチイワシ やマイワシなどの低価格の浮魚類の漁獲割合が高く なった.このような傾向は関根ら ${ }^{19)}$ によると海域の 貧酸素水塊の発生が水産資源量の制的関数になって いるという報告と関連性が見られる。これと関連し 
て, 永井 ${ }^{20)}$ は水産の立場からの窒素とリンに関する 望ましい環境基準を提案している. Fig. 11 は瀬戸 内海のリン, 窒素の目標水質を達成するために, 各 灘の流入負荷量をどれだけ削減しなければならない かを Table 4 に基づいて試算した適正流入負荷量の 推算結果である. 水質の目標浱度は永井 ${ }^{20}$ の報告を 用いて，上述した現状筁度と同様の方法で，各淎の 年平均値として算出した.これは Fig.11に Target として表現されているものである.これらの值をも とにモデの再現性を評価した. ただし，本モデル は灘平均濃度しか扱えないので，沿岸域之沖合の目 標水質の逗いといった細かい部分は評価できない。

Fig. 11 の Case 1 は, 負荷量削減の上限を $30 \%$ と してできるだけ目標水質を達成しようとしたもので あるが, 瀬戸内海東部では目標值を達成できない. Case 2 は効率的に目標值を達成できるよう最適化 した場合である．備鿁瀬戸から大阪湾にかけては T Nでは $30 \%$ ～ $80 \% ，$ T Pでは $60 \% \sim 65 \%$ の負 荷削減が必要であり, 目標水質を達成するためには かなりの努力が必要なことがわかる。

\section{（4）負荷量と水産資源}

上記では水産側から提示された富栄䓹レベルを達 成するためには，西部ではむしろやや富栄養化の方 向にシフトしてよいところもあるが，東部では大阪 湾, 備讃瀬戸などでかなりの負荷削減が必要という ことが示されている．しかし，負荷量と漁獲量の関 連性を探るためには，負荷量から魚へのメカニズム を把握することが必要である．そのため，負荷量か ら，慨となるプランクトンの一次生産，そして水揚 量へと段階的に検討した.

\section{a) 負荷量と一次生産量の対応}

まず，上記の長期シミュレーションを用いて，一 次生産量 (生産量一分解量) の経年值を得た. Fig. 12 (B) に, 1962 年から 1987 年までの， 5 年ごとの 計算結果を示す. Fig.12によると, 瀬戸内海全域 で見てもほほ負荷量と一次生産量は比例しており， ある灘だけが特別に負荷量に対する一次生産の対応 の度合いが異なるといったことはないようである。 以上のことから, 負荷量が増えれば，どの淎も一次 生産は増加する傾向が見られた。

\section{b) 一次生産量と漁獾旦}

負荷量の増加により，一次生産量が増すことは確 認されたが，こうして増加した慨によって，魚はど の程度増加するのかを検討した. Fig. 13 に上述の モテルによる一次生産の経年計算值と瀬戸内海淎別 の漁獲量統計より算出した窒素, リン水揚量 ${ }^{13)}$ を全 灘の比較で表している．図を見ると，1962～ 1967
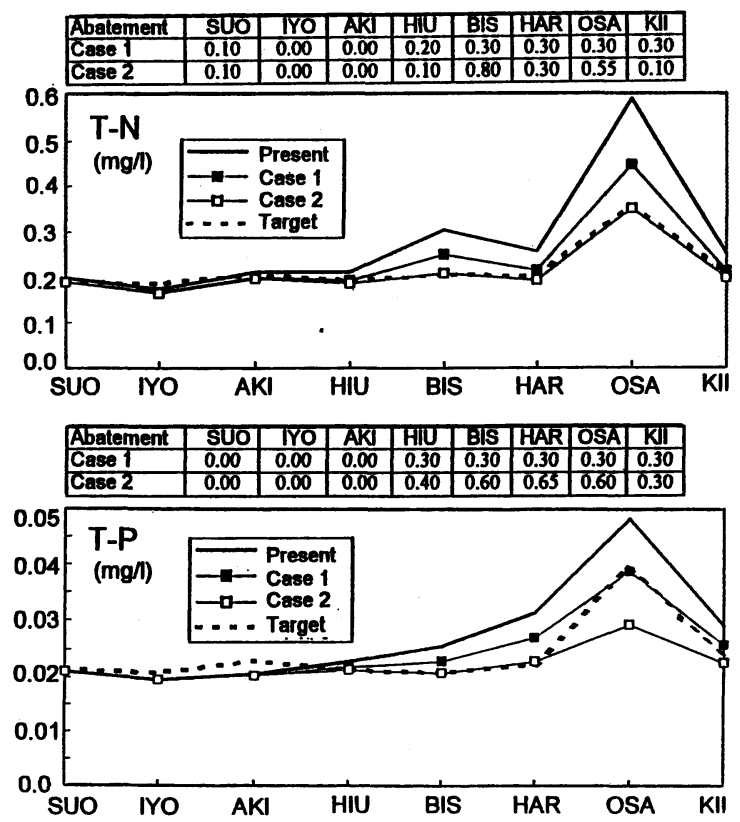

Fig. 11 Comparison between targeted water quality and optimited loading abatement calculated by numerical simulation in Seto-Inland Sea.
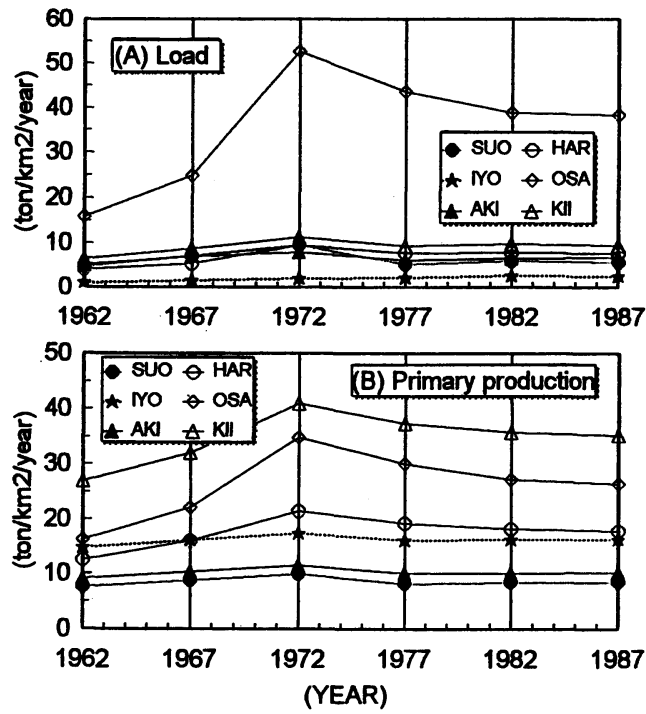

Fig. 12 Correspondence of load and primary production for TN in Seto-Inland Sea.

年にかけては，一次生産量の高い灘か，水揚量も高 い傾向を見せている．しかし，一次生産量の最も高 い海域である大阪湾に着目すると，1962 年から一 次生産量のピークとなる 1972 年にかけての水揚量 に上昇は見られない，個別の灌について，一次生産 量と水揚量の経年変化を見ると，一次生産量の増加 に対する水揚量の増加は，大阪湾については確認さ 
れない，安芸灘に関しては，一次生産量の増加時期 に水揚げは減少すらしている，㥞灘と播磨灘などで は, 最初は幾らか水揚げの増加が見られるが，一次 生産の増加に比へると, やや纊慢な増加で, しかも, ある時期から, 一次生産量の增加に対して, 水揚量 の伸び悩みが見られる.これらのことから，ある程 度までの一次生産量の増加は水揚量の増加につなが るが, それ以上一次生産量が増えても水揚量の伸び は期待できないと考えられる.

c）負荷量と水産資源の関係

負荷量の増加は一次生産量を増加させているが一 次生産量が，そのまま漁獲の増加につながってはい ないとの結果を得た.これは, 負荷量から一次生産 まではエネルギーが伝達するが，ある量を越えると， 2 次生産以降の伝達に限界を生じるためである. つ まり, 負荷の増加は, そのまま水揚量の増加につな がる訳ではなく，その効果にも限界があると言える. 特に大阪湾においては, 負荷の増加にともなう水産 資源の伸びは期待できない，ある程度の富栄誉化は， 水産資源の伸びにつながるということは既に知られ ている ${ }^{21}$ ．本研究においても，負荷の増加にともな う幾らかの水揚量の伸びは確認されたが，過㮃な負 荷は, 水質の悪化を招くだけで, 水産資源の伸びに はつながらない，瀬戸内海のほとんどの海域は，こ れ以上の富栄養化による水産資源の伸びは期待でき ないと言える.

\section{d）適正富栄養化レベル}

Fig. 14 に灘別の面積当たりの流入窒素負荷と生 産金額の関係，同じく水揚負荷との関係を示す. 面 積あたりの負荷が増大すれば両者とも増加するが, ある程度以上大きくなると, 頭打ちになり，とくに 生産金額については減少傾向を示す（詳細は文献 ${ }^{13)}$ 参照）。ちなみに水揚げによる負荷の回収率は 19 87 年の播磨灘で窒素 $11 \%$ ，リン $21 \%$ と最大を示し ていろ. 仮に, この播磨灌の面積負荷を水産業にと っての最適条件とすると，窒素では 10 トン $/ \mathrm{km}^{2} /$ 年あるいは $27 \mathrm{mg} / \mathrm{m}^{2}$ /日の面積負荷となる. いず れにしても水産業から見た場合, 当然地域的に状況 は異るものの，ほぼ現状に近いレベルが許容される と考えられる．また，負荷のみではなく，定量的評 価は不十分であるが，藻場，干潟など浅海部の改変 が水産業に与える影響も大きい，瀬戸内海における 負荷削減は水産面より海水浴や景観など別の面から の要請によることになろう.

\section{4. 結論}

本研究では, 瀬戸内海を対象として, 水・底質モ
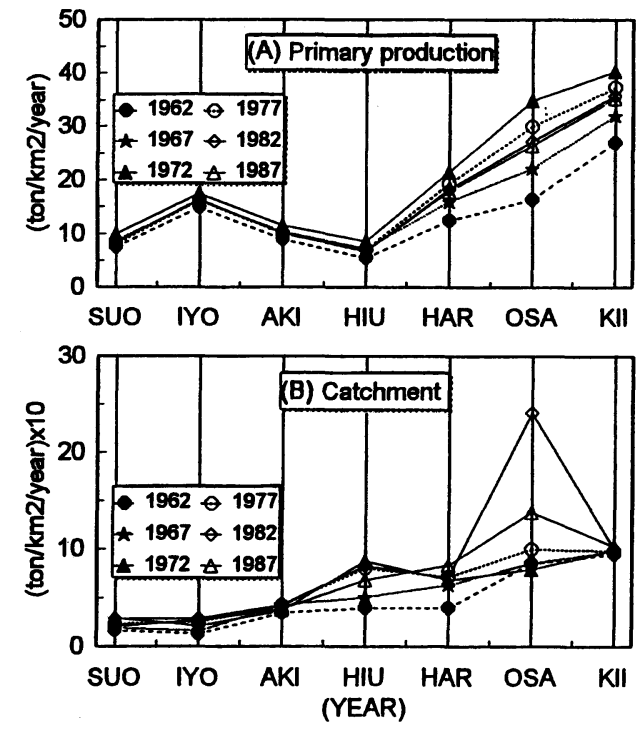

Fig. 13 Correspondence of primary production and catchment for TN in Seto-Inland Sea.

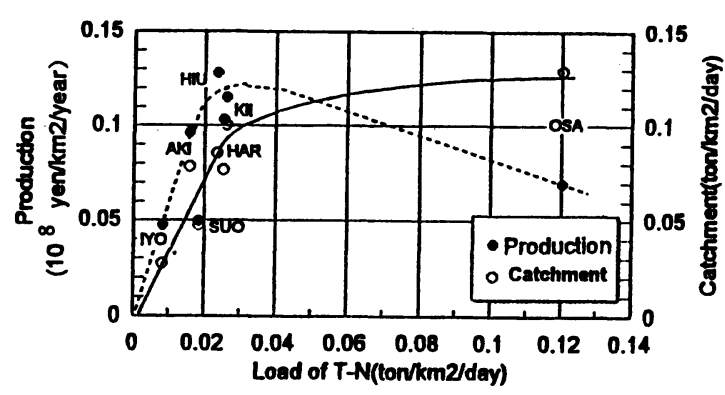

Fig. 14 Correspondence of load, catchment, and production for TN calculated unit per area in each BOX.

テルを用いて，灘ごとの負荷と水質の応答特性，負 荷削減の影響解析とともに負荷一水質一水産資源の 3 者の相互関連性から水質管理について研究を行っ た. 以下に本研究で得られた成果を要約する.

(1) 水・底質の間の溶存酸素と栄盖塩の授受によ る水質の季節変化モテルを作成した.

（2） 1957 年から 1987 年までの実際の負荷を与え て，この 30 年間にわたる長期シミュレーションを 行い, 水質や一次生産量の経年変化の值を得た。 こ れらから，篊によっては，負荷量一水質の応答に違 いがあることが分かった. また，備謮瀬戸から大阪 湾にかけて目標水質を達成するためにはかなりの改 善努力が必要なことが解った.

（3）適正負荷量の推算方法として，隣接海域の影 帮や寄与率を含む，負荷削減後の水質予測に対する 概算式を提案した.

（4）負荷量の削減効果の数值計算より, リンのみ 
ならず窒素の負荷削减の影幚が大きいことを示した.

（5）負荷と水産資源の関連を，水質を介在させて 検討し, 瀬戸内海では, 負荷の増加は一次生産量の 増加につながるが， 2 次生産以降のエネルギーの伝 達には限度があることを示した。

\section{参考文献}

1) 合田 健 : 沿岸海域の $\mathrm{N}, \mathrm{P}$ 渨境基準, 水環境学会 誌, Vol.16, No.8, pp.533， 1993.

2) 内田唯史, 浮田正夫, 関根雅彦, 中西 弘: 富栄意 化海域の水質の非線形性とそのモテリングに関する 研究, 土木学会論文集, 503/ II -29, pp.187-195, 1994.

3) 中田喜三郎, 田口弘一 : 生㿟心一流体力学モテルを用 いた内济の富栄緟化過程に関する数值実検，その2，

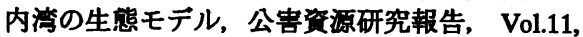
No.4, pp.47-69, 1982.

4) Kishi, M., K. Nakata and K. Ishikawa : Sensitive Analisis of a Coastal Marine Ecosystem, J.Oceanogr.Soc. of Japan, Vol.37, pp.120-134, 1981.

5) 松梨史郎：閉鎖性海域の窒素・リン・溶存酸素の予 湘モテル, 海岸工学論文集, 第 40 巻, pp.1076-1080, 1993.

6) 浮田正夫, 中西弘, 河合泰治, 松村和紀 : 富栄秦化 水域における底質評価に関する研究，土木学会論文 集, 第 357 号, pp.235-242, 1985.

7) 浮田正夫, 山原康䦜, 中西弘: 大阪滈における流入 負荷量の推移亡内部生産, 沿岸海洋研究ノート, 第 29 巻, 第 1 号, pp.51-59, 1991.

8) 小坂淳夫 : 㖽戸内海の環境, 恒星社厚生閣, pp. 342 , 1985.

9）李寅鉄, 浮田正夫, 関根雅彦, 藤田健一 : 瀬戸内海 における流量収支と水質応答特性に関する研究，罢
境工学論文集, 第 32 巻, pp. 293-300, 1995.

10) 山田 久: 堆稓有機物の分解 - 無機化之栄荃塩類の 溶出について, 内幥底泥をめぐろ物質収支の動照解 明に関する研究, 水産庁, pp. 218, 1983.

11）奥川光治, 宗宮功 : 水理モテルによる富栄養化のシ ミュレーション解析, 土木学会論文集, 第 337 号, pp. 119-128, 1983.

12）環境庁水質保全局 : 広域総合水質調查結果，1984 $\sim 1989$.

13）李寅鉄, 浮田正夫, 関根雅彦, 中西弘: 㖽戸内海一 の栄意塩類の流入負荷解析之物質収支に関する研究, 海岸工学論文集, 第 42 巻, pp.1106-1110, 1995.

14）大阪府環境局理境保全部 : 大阪府水質測定結果表, $1972 \sim 1989$.

15)水産庁 : 広域総合水質調查結果, 1987.

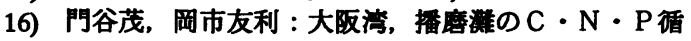
㻴におけろプランクトンの役割, 沿岸海洋研究ノー 卜, 第 25 巻, 第 2 号, pp.158-164, 1988.

17) 中西弘, 浮田正夫 : 環境における公素,リンの収支 および水域の受容能力と対策, 日本河川水質年鍍 (1982), pp.863-880, 1983.

18) 城 久: 大阪湾の開発と海域環境の変䢰, 日本海洋 学会秋季大会暲演要旨集, pp.329-330, 1990.

19）関根雅彦, 李宙鉄, 浮田正夫, 今井岡, 楢崎寿晃, 中西弘 : 瀬戸内海渵場生舁系モテルにおける溶存酸 素の取り扱い, 棵境工学論文集, 第 32 巻, pp. 301 $-310,1995$.

20）永井迋樹：望ましい漁業，瀬戸内海の生物資源之㻴 境一その将来のために一（岡市友利螎），恒星社 厚生閣, pp. 83-105, 1996.

21）中西 弘：水域の富栄荃化にかかろ流入負荷とその 制御, 頼戸内海科学, 第 1 巻 ( 3 号) , 1990.

\title{
STUDY ON THE WATER QUALITY MANAGEMENT IN SETO INLAND SEA BY USING THE WATER AND SEDIMENT QUALITY MODEL
}

\author{
In-cheol LEE, Masao UKITA, Masahiko SEKINE and Hiroshi NAKANISHI
}

By using the water-sediment quality model (WSQM), the numerical experiments were carried out for the management of water quality in the Seto-Inland Sea. A formula roughly forecasting water quality to estimate the effect of loading abatement was proposed. According to analysis of loading abatement, it was shown that relatively large effort of abatement would be required in the eastern Seto-Inland Sea, from Bisan Seto to Osaka bay, and that not only TP but TN load abatement was also required. On the other hand, it was indicated that the increase of loading lead to increase of the primary production, while not straightly to increase of fish catchment. 